\title{
The Development of Geographic Information System using Participatory GIS Concept of Spatial Management
}

\author{
Nizar Rabbi Radliya ${ }^{1}$, Rauf Fauzan ${ }^{2}$, Hani Irmayanti ${ }^{3}$ \\ Information System Department ${ }^{1,2}$ \\ Computer Engineering Department ${ }^{3}$ \\ Universitas Komputer Indonesia, Bandung, Indonesia
}

\begin{abstract}
Spatial management of Bandung Regency area has been regulated on Regional Regulation (PERDA), which is PERDA Bandung Regency Number 27 of 2016. Recently there are no facilities that can be used as a dissemination media of information about The Regional Layout Planning (RTRW) so that it easily accessed by the community who will utilize the space in Bandung Regency area. The information dissemination of The Regional Layout Planning is very important to avoid the mistake in the use of the area by the community. The use of Participatory GIS is conducted based on the purpose of producing an appropriate spatial plan in accordance with the established rules. The implementation of participatory GIS concept on the geographic information system of regional spatial allows all communities to participate in making decisions on the use of an area.
\end{abstract}

Keywords-Participatory GIS; regional spatial planning; geographic information system

\section{INTRODUCTION}

\section{A. Background}

According to the Law of The Republic of Indonesia Number 26 of 2007, spatial is the residential centers, infrastructure network systems which function as a support for the society's social economic activity which has a functional relation in a hierarchy [1]. Spatial management of Bandung Regency area has been regulated on the Regional Regulation of Bandung Regency Number 27 the year 2016 about spatial planning of Bandung Regency area for 2016-2036 [2]. Recently there are no facilities that can be used as a dissemination media of information about The Regional Layout Planning (RTRW) so that it easily accessed by the community (individual or groups communities such as customary law communities and corporations) who will utilize the space in Bandung Regency are. The information dissemination of The Regional Layout Planning is very important to avoid the mistake in the use of the area by the community. In the Regional Regulation of Bandung Regency Number 27 the Year 2016 stated that the information dissemination of RTRW can be conducted by utilizing information Technology and Communication (ICT). The utilization of ICT can be conducted by creating a geographic information system.

The use of geographic information system also can be used for providing the information of the infrastructure in Bandung
Regency area in the form of spatial data (maps). The provided information is administrative map (include: districts, central government, rivers, roads, villages), pattern design map (include: includes railways, tourism areas, main energy, mines), the land users map, map of the network system for facilities and infrastructure (include: maps of land transportation infrastructure plans, maps of railway infrastructure plans, maps of residential neighborhood infrastructure plan, maps of energy network plan, maps of water resources infrastructure plans, maps of telecommunication infrastructure plan, maps of air transportation infrastructure plan).

In the development of geographic information systems in this study will utilize the concept of Participatory GIS because this method can produce more comprehensive results compared to other commonly used methods [3]. The use of the Participatory GIS concept is based on the purpose of producing appropriate spatial planning in accordance with Bandung Regency Regional Regulation Number 27 of 2016. Regional development that conducted with appropriate spatial planning can have a positive impact on the welfare of many communities [4].

Based on the description above, this study intends to develop a geographic information system that can be utilized by the local government of Bandung Regency in disseminating information about the Regional Spatial Plan (RTRW). The application of the Participatory GIS concept can enable people to participate in making appropriate spatial planning of Bandung Regency area.

\section{B. Research Problems}

Based on the description of the research background, the research problems are as follows:

1) How is the dissemination of information about the Regional Spatial Plan (RTRW) in Bandung Regency so that it is easily accessible to the public who will utilize space in the Bandung Regency area?

2) How is the application of the GIS Participatory concept to the development of geographic information systems in the spatial management of Bandung Regency area? 


\section{Objectives of Research}

The objectives of this study are as follows:

1) Disseminate information about the Regional Spatial Planning (RTRW) in Bandung Regency in accordance with the Bandung Regency Regional Regulation Number 27 of 2016.

2) Implementing the GIS Participatory concept in the development of geographic information systems in spatial management of Bandung Regency.

\section{Research Benefits}

The benefits of this research are solving several problems in regional spatial management, as follows:

1) The benefits for the community: Obtain information about the Regional Spatial Planning (RTRW) in Bandung Regency in accordance with the Bandung Regency Regional Regulation Number 27 of 2016.

2) The benefits for the local government: Assist in management of regional spatial planning, space utilization, and control of spatial use.

\section{LITERATURE REVIEW}

\section{A. The Previous Research}

Some studies are stated to be related because there are similarities in research themes, it is about spatial mapping. One of the studies related to spatial mapping is the research with the title of integrating participatory GIS into spatial planning regulation: The case of Merauke District, Papua, Indonesia [5]. In the study stated that the community needs urban spatial information that is displayed in detail so that the information can be used as a guide or reference in carrying out the planning, development, and improvement of each region in this country. On the basis of the research statement, the researchers plan to conduct research that aims to develop a geographic information system for spatial management in the Bandung Regency area.

Other related research is a study entitled The Study of Integration of "GIS Participatory-Decision Support" in Regional Spatial Management [6]. In this study, it was limited to a literature study on the system of development planning and spatial planning as well as the prospects for applying Participatory GIS information technology and multi criteria decision analysis methods applied to the aspects of spatial management. While in this study, the development of the research results will be conducted in the form of a Web-based Geographic Information System using the concept of Participatory GIS.

\section{B. Geographic Information Systems}

Geographical information system is a computer-based system built with the purpose of collecting, storing, analyzing, processing and presenting information related to the location of an object or its existence on the surface of the earth [7]. In this study will be conducted the development of a geographic information system for the spatial management of Bandung Regency. The information system developed will present the spatial data for the presentation of regional maps and equipped with information for each map of the area that displayed.

\section{Participatory Concept of GIS}

In the development of geographic information systems in this study will utilize the concept of Participatory GIS. It is a geographical information system that operates on the internet with the purpose of gaining broad public participation [8]. Fig. 1 shows the GIS Participatory architecture.

Regional development that performed with appropriate spatial planning can have a positive impact on the welfare of many people. In order to produce appropriate spatial planning, it requires the participation of the entire community in making decisions on the use of an area. So that the resulting of the space placement plan can represent the interests of all community groups and local residents [9].

\section{The Spatial of Bandung Regency Area}

Spatial planning is the distribution of space functions in a region which includes protected functions and cultivation functions [1]. The Spatial Planning System in Indonesia can be seen in Fig. 2 below.

Fig. 3 shows the pattern map of the Bandung regency area.

In the Regional Regulation document of Bandung Regency No. 27 of 2016, the scope of RTRW in Bandung Regency describes the implementation strategy for the use of regional space up to land, water, and airspace boundaries according to applicable regulations and laws, located at 6o 49 '- 7o 18 'South Latitude and between 107o 14' - 107o 56 'East Longitude with an area of Bandung Regency approximately 176,238 hectares consisting of 31 sub-districts [2].

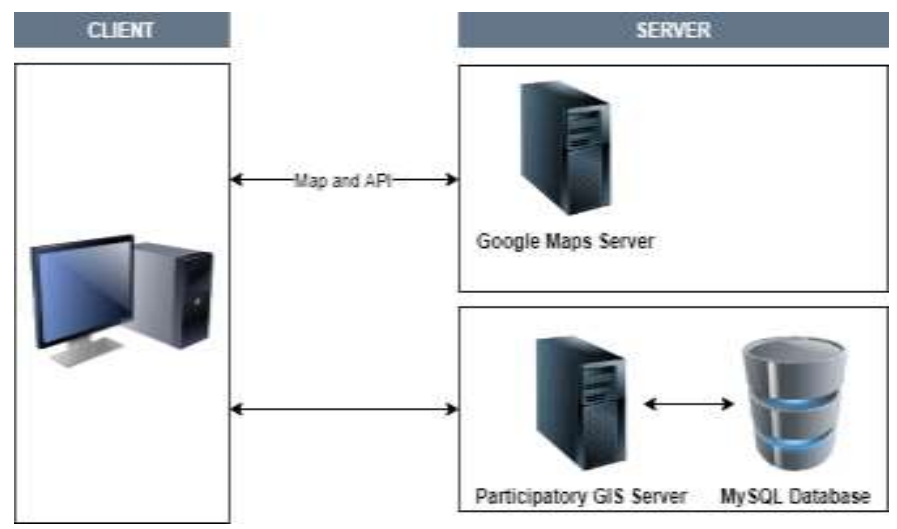

Fig. 1. Participatory GIS Architecture [8]. 


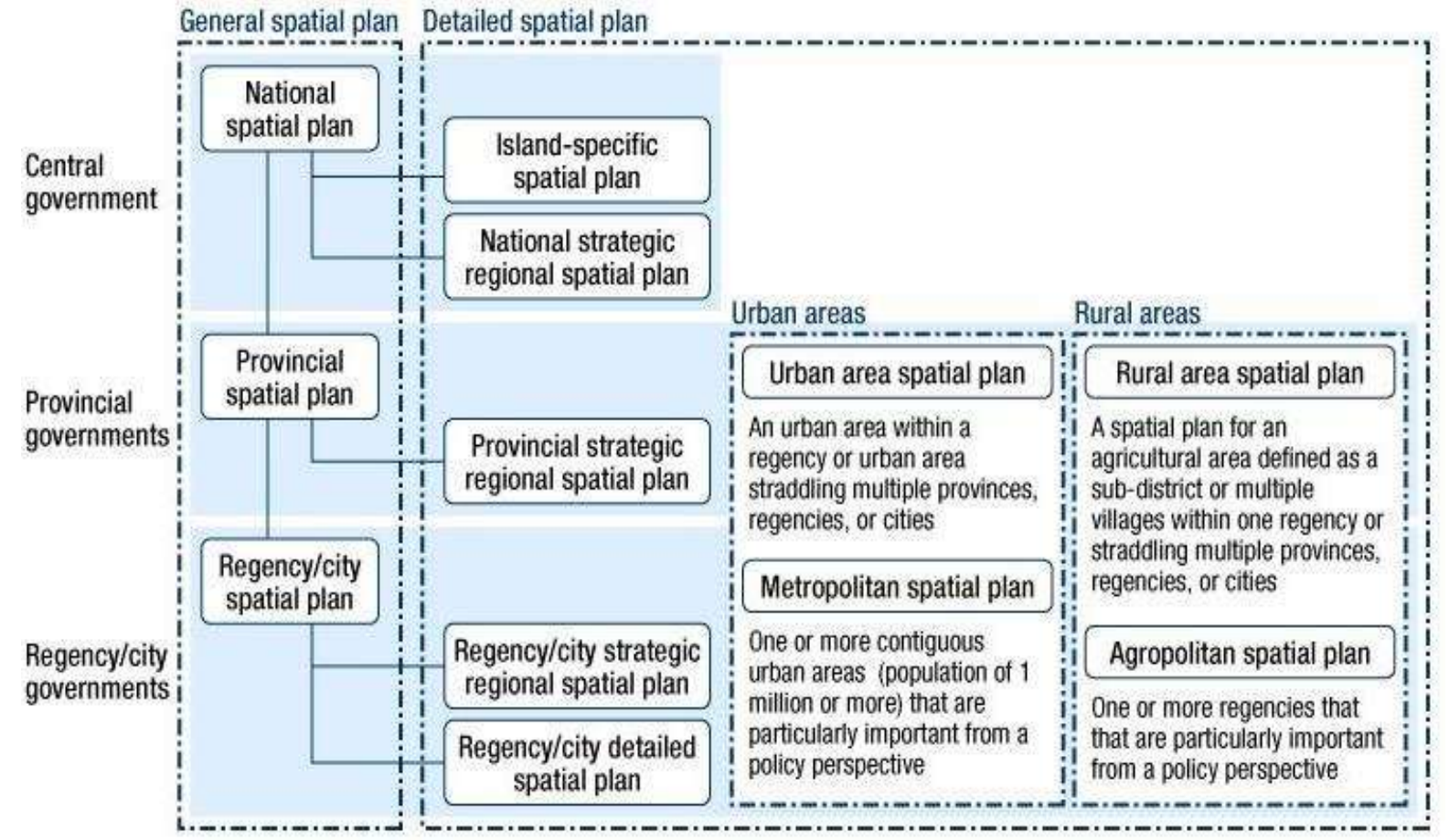

Fig. 2. Spatial Planning System in Indonesia [10]

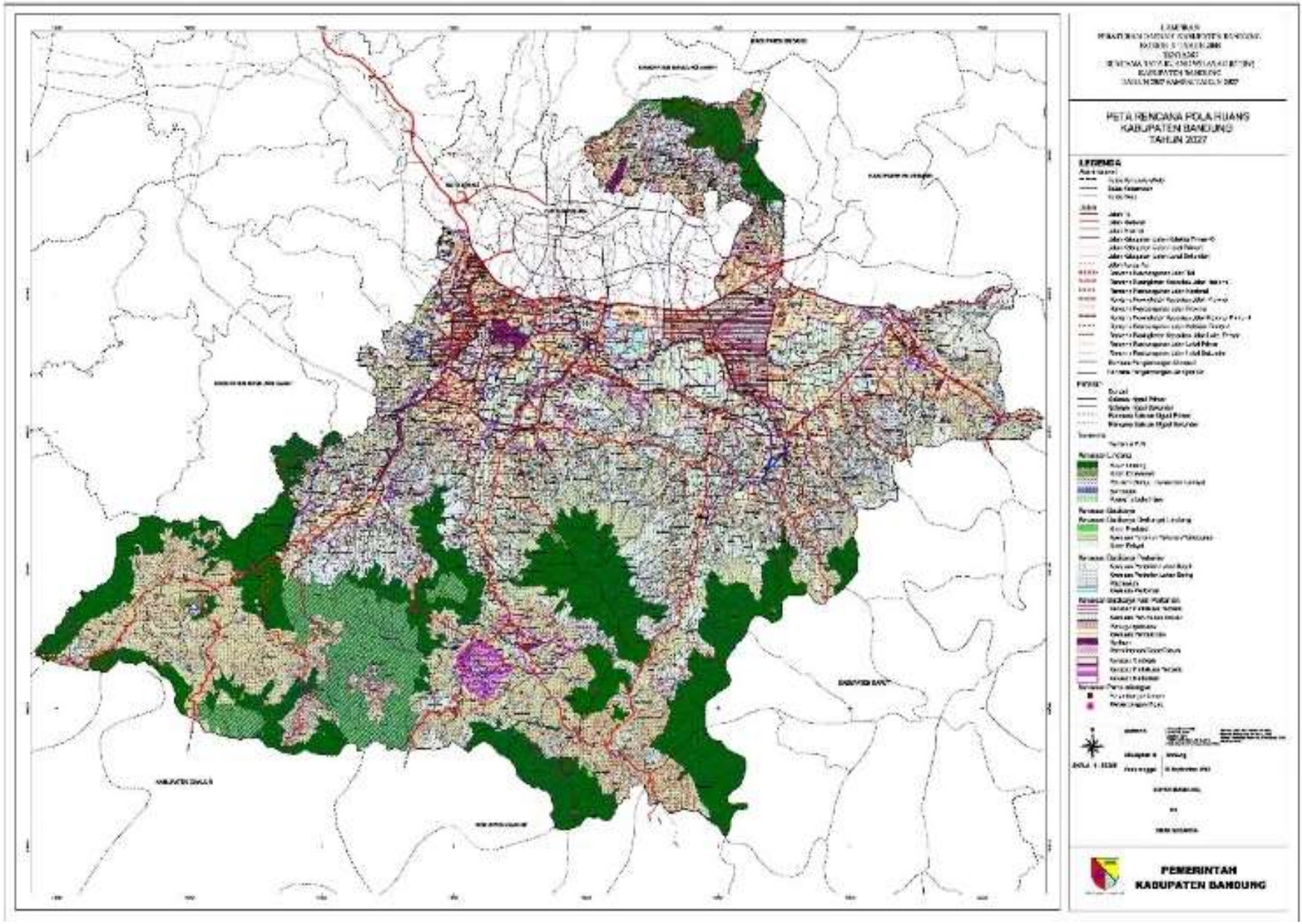

Fig. 3. Regional Pattern Map of Bandung Regency [2]. 


\section{ReSEARCH Methodology}

\section{A. Research Method}

Research and Development (R\&D) method is a research method to produce certain products and test the effectiveness of these products. This research method focuses on the needs analysis, the development and testing of the level of the product so that it can function or benefit for the community (research object) [11].

The basic selection method because this research will produce a product in the form of a software application. The $\mathrm{R}$ \& D method used will play a significant role in the design and trial activities of the developed application.

\section{B. Approach and System Development}

The system approach used in this study is an objectoriented approach. This method is an approach technique that views the system as a collection of objects that are mutually bound one to another. Each object in the system has attributes and characteristic/ functions [12].

The system development methodology used is RAD (Rapid Application Development). RAD is an object-oriented approach to system development that includes a method of development and software. Fig. 4 below shows the cycle of RAD.

\section{Data Collection and Analysis Techniques}

Primary data collection used interview techniques. The interview is a question and answer activity to get information for research purposes using guidelines [12]. In this study, the interviews were conducted on the research subjects, Renbang LH and Spatial Planning division of Bappeda Bandung Regency.

Secondary data collection used library research techniques by searching of the library data that supports the research theme. The literature can be in the form of books, scientific journals and e-books. The requirements of research data are also obtained from several documents related to Basic Maps, Spatial Pattern Maps, Land User Maps and the Maps of Network Systems Plan for Facilities and Infrastructure.

Data analysis technique that is used in this research adjusted with the approach method and the development system that has been determined. It because this research purposes to do the improvement of the system such as an application. The tool of system modeling documentation used diagram of UML version 2.5 (Unified Modeling Language).

\section{Subject of Research}

This research was conducted in the Renbang LH (Live Environment) and Spatial Planning division of BAPPEDA Bandung Regency, its address at Jalan Raya Soreang kilometer 17 Government Complex of Bandung Regency, West Java Province. Basically, the developed application in this study is intended for people who will utilize space in Bandung Regency area.

\section{E. Research Procedure}

Research procedures based on research methods of Research and Development (R\&D) combined with the system approach and development methods are used. As for the steps are as follows:

1) Phase I Requirements Planning: on the stage of the preliminary research study was conducted to determine the scope of the research. This step begins with understanding the problems of Spatial Planning area (RTRW) in Bandung Regency. It is also conducted a study of literature and library related concepts of geographic information systems and the application of the concept of Participatory GIS toward the research that will be done. The final result of this step is to describe the finding of related problems to RTRW in Bandung Regency.

2) Stage II RAD Design Workshop: Stages of RAD Design Workshop is a stage that is conducted by collaborating with users, specifically the Renbang LH and Spatial Planning Division. This stage includes two main stages including the design of the system and the implementation of the design results in the form of an application program. Both of these stages are performed repeatedly, until the condition that the application has been agreed by the user, the LH Renbang and Spatial Planning Division.

3) Phase III Implementation: The last stage is implementation. This stage begins with defining technical guidelines for hardware (Computers / Servers and Networks) to support the development and implementation of applications in accordance with the terms and conditions of the system designed. Next, install the application by uploading applications and databases into a VPS (Virtual Private Server) server. Finally, conduct socialization and training, this can be done in several ways. For operator level (internal users) training is conducted on the job training. As for the general public, it is conducted by sounding first to several districts.

Fig. 5 below shows the Implemented research procedures.

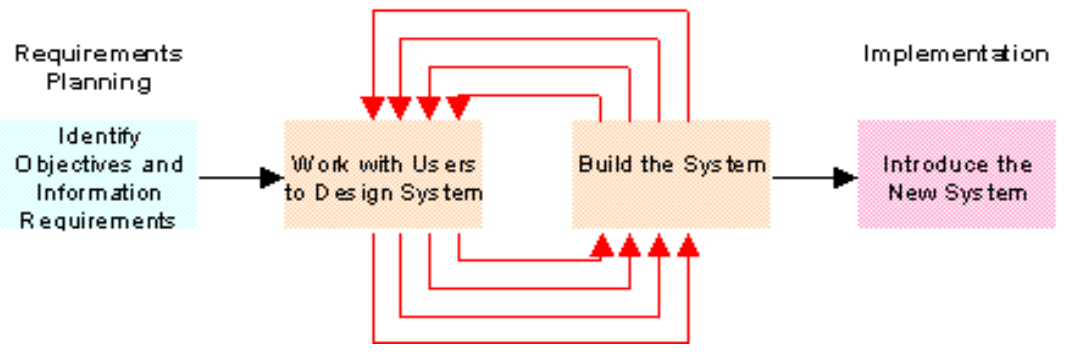

Fig. 4. RAD (Rapid Application Development) Cycle [11]. 


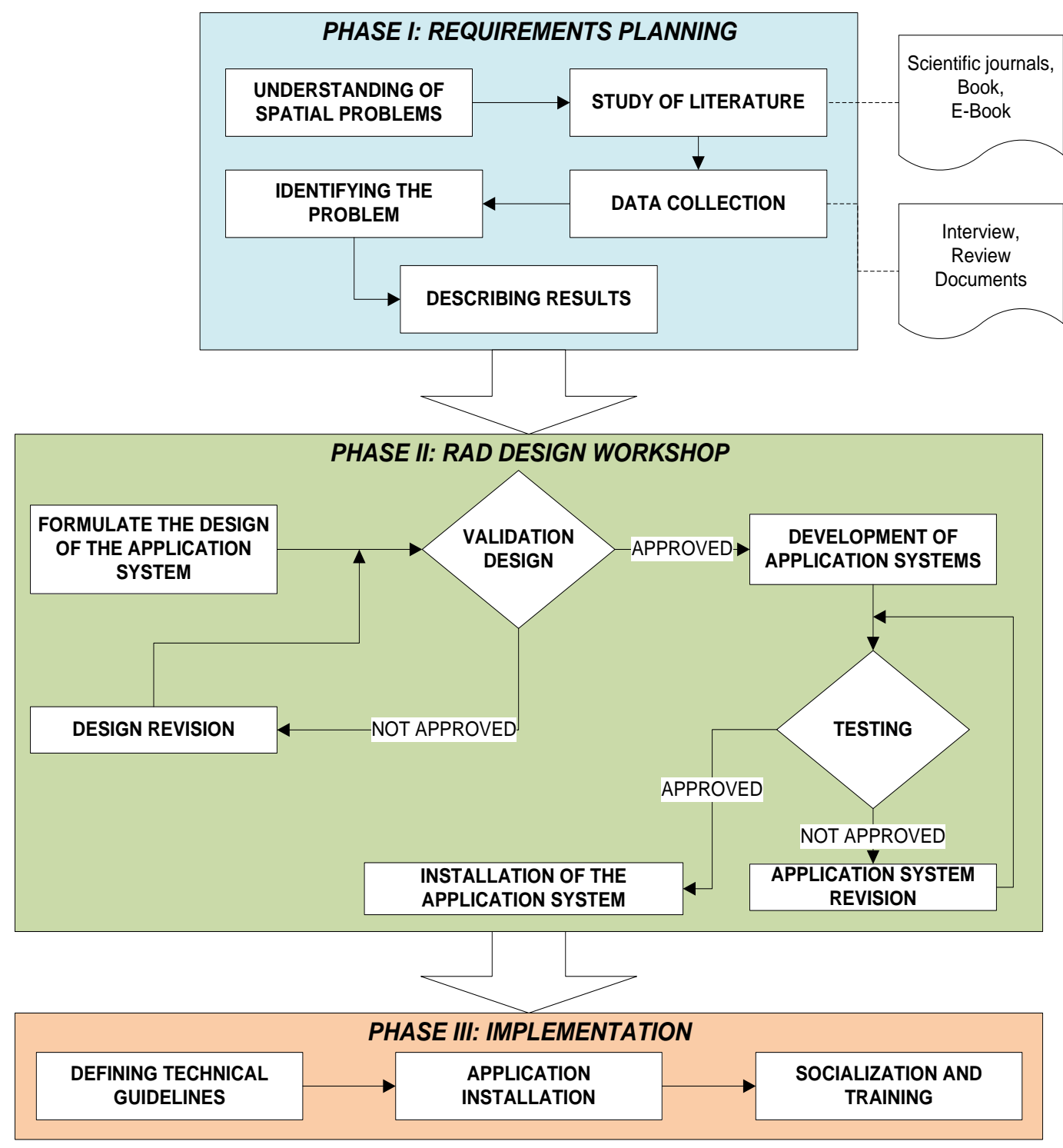

Fig. 5. Research Procedure.

\section{RESUlT AND DISCUSSION}

\section{A. System Analysis}

The procedures related to the information dissemination of RTRW which still ongoing in Renbang LH and spatial planning division of BAPPEDA Bandung Regency are as follows:

1) Public community directly visit the district or BAPPEDA office to submit the document of related information of utilizing area/related spatial land in Bandung Regency area.

2) Renbang LH and Spatial Planning division of BAPPEDA do the validation of related to the submission information, then check by looking the map data documents

3) After reviewing the application and adjusting it to the map of the possessed data, Renbang LH and spatial planning division of BAPPEDA give the information to the community who submitted, related to area utilization/ land requested in writing.

Fig. 6 below shows use case diagram of a result of the proposed system design.

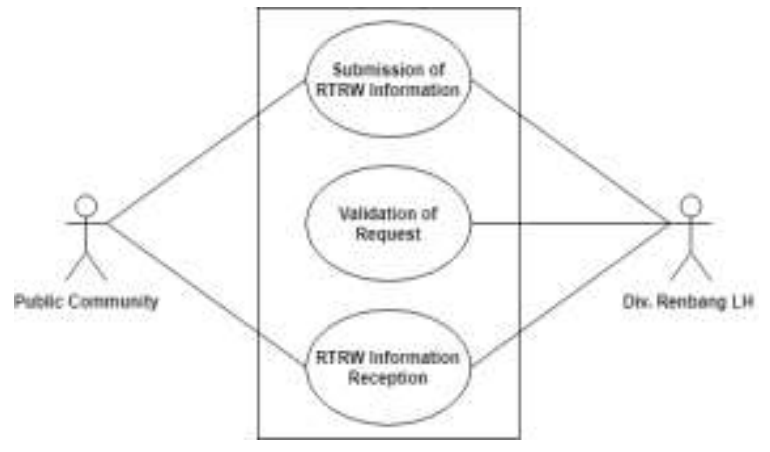

Fig. 6. Use Case Diagram of Information Dissemination of RTRW in Bandung Regency. 


\section{B. System Design}

In designing this system, the improvement of the running system will be done, wherein the running system the dissemination information process of map related to RTRW of Bandung Regency is still done manually. Fig. 7 below shows use case diagram of a result of the proposed system design modeling.

In the geographic information system (GIS) of RTRW Bandung Regency involve $d$ three actors (access right/users). The communities are required to register in advance if they plan to get the information about RTRW map and they also are required to fill the questionnaire of the objective for utilizing the area. Renbang LH and spatial planning division in BAPPEDA can upload the document files related to RTRW of Bandung Regency. Furthermore, the file can be downloaded by the community. While for the administrators can manage questionnaire data so the information about the objective for utilizing the area can be found by the community. The management of RTRW map also can be conducted by the administrator with the purposes to update RTRW map in Bandung Regency if there is change/development. The map management also used software tools, ArcGis and Geoserver.

\section{System Development}

The results of the design are implemented in the form of web-based programs or applications. There are several tools that are used in program development, including web server using Xampp, IDE using PHPStorm, web browser using Mozilla Firefox and map implementation using ArcGis and GeoServer.

Program user access rights are divided into three, according to system design, they are the community, internal users (LH Division and Spatial Planning), and administrators. People who will access the RTRW map are required to register while filling out the questionnaire on the page provided as shown in Fig. 8 below.

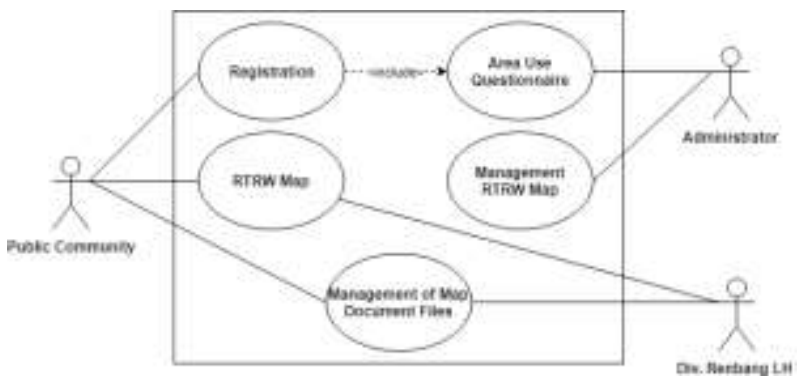

Fig. 7. Regional Pattern Map of Bandung Regency [2].

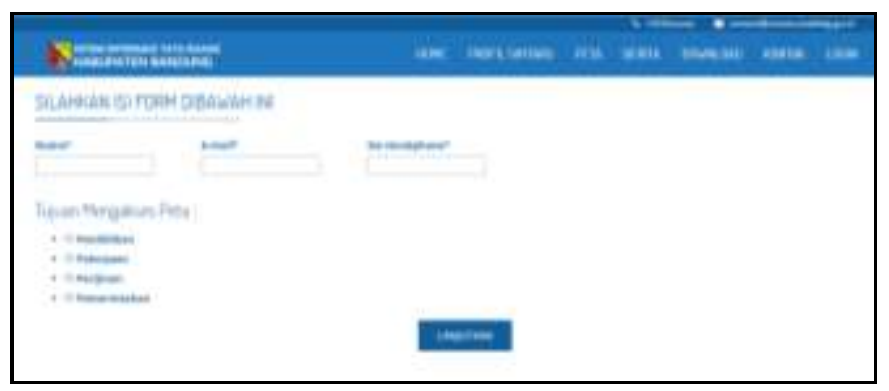

Fig. 8. Register and Questionnaire Form.
When you successfully register so username and password will be sent via email that has been registered. Later the society can $\log$ in to access RTRW map. Fig. 9 below shows the application display of RTRW map.

The community can get the information about RTRW of Bandung Regency in the form of map. That map is equipped with searching facility based on the type of the map designation, coordinate, and searching based on the area. If the cursor is pointed out to a particular part on the map so it will appear the detail information of each selected area.

Renbag LH and spatial planning division can upload document file related to RTRW of Bandung Regency then that fille can be downloaded by the community. Fig. 10 below shows the application interface for document management.

The Administrators can process questionnaire data so that information about the purpose of the area utilization is known by the community as shown in Fig. 11 below.

Map management of RTRW can be done by the administrator in order to update of RTRW map in Bandung Regency which used ArcGis and Geoserver as software tools. Fig. 12 below shows the application interface to manage map management of RTRW in Bandung Regency.

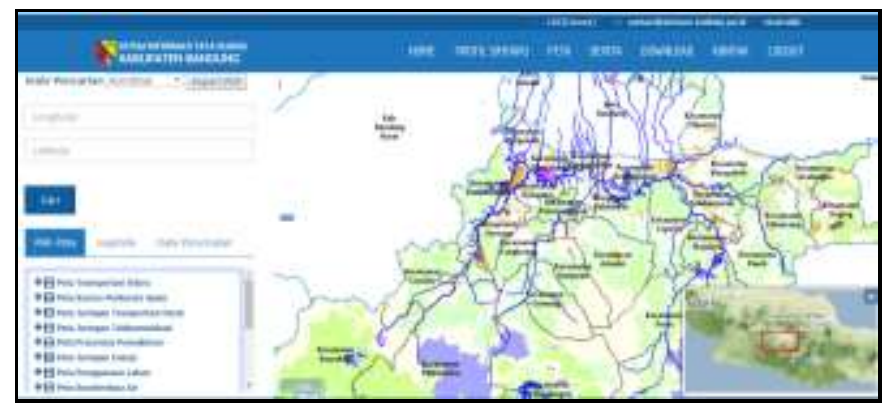

Fig. 9. Geographic Information System of RTRW in Bandung Regency.

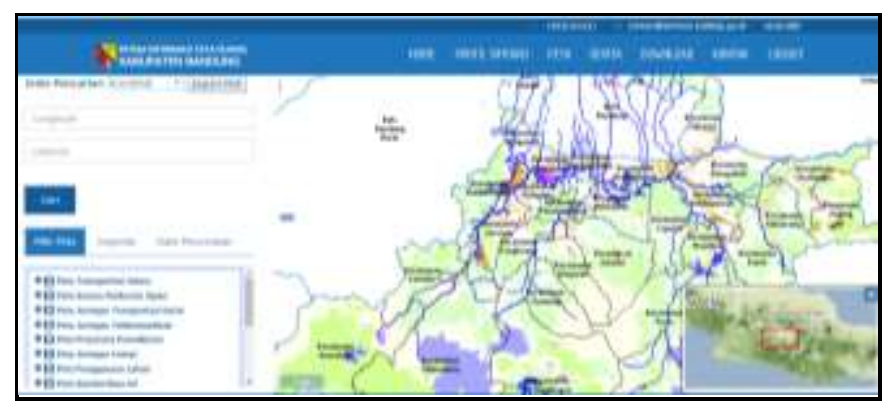

Fig. 10. Management of Map Document Files.

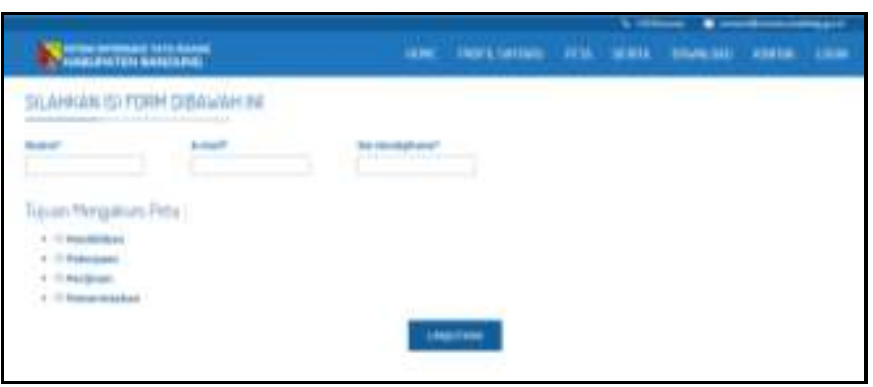

Fig. 11. Area Questionnaire Result of Area Utilization. 


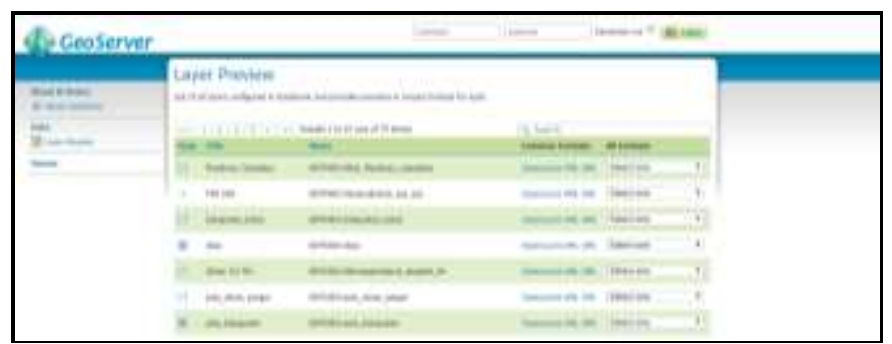

Fig. 12. Map Managing using GeoServer.

TABLE I. Planning AND System Testing

\begin{tabular}{|c|c|c|c|}
\hline No & Test Item & Test element & Result \\
\hline \multirow{2}{*}{1} & \multirow{2}{*}{ Registration } & $\begin{array}{l}\text { Validation of registration } \\
\text { input form }\end{array}$ & \multirow{2}{*}[\sqrt{}]{ Accepted } \\
\hline & & Coherence Result & \\
\hline \multirow{2}{*}{2} & \multirow{2}{*}{ Login } & $\begin{array}{l}\text { Validation user } \\
\text { authentication }\end{array}$ & \multirow{2}{*}[\sqrt{}]{ Accepted } \\
\hline & & Coherence Result & \\
\hline \multirow{2}{*}{3} & \multirow{2}{*}{ Quisionare } & $\begin{array}{l}\text { Validation of questionnaire } \\
\text { form }\end{array}$ & \multirow{2}{*}[\sqrt{}]{ Accepted } \\
\hline & & Coherence Result & \\
\hline \multirow{2}{*}{4} & \multirow{2}{*}{ RTRW Map } & $\begin{array}{l}\text { Validation of map } \\
\text { searching form }\end{array}$ & \multirow{2}{*}[\sqrt{}]{ Accepted } \\
\hline & & Coherence Result & \\
\hline \multirow{2}{*}{5} & \multirow{2}{*}{$\begin{array}{l}\text { Upload File } \\
\text { Map document }\end{array}$} & Validation of upload form & \multirow{2}{*}[\sqrt{}]{ Accepted } \\
\hline & & Coherence Result & \\
\hline
\end{tabular}

D. System Testing

Black box testing will be used in the trial step. It serves to find whether the developed program already has a function in accordance with the design provision [13]. Testing planning is conducted by using input data from users. In Table 1 above show that planning and result of a trial system.

Based on the last trial can be concluded that the developed system already fulfill all the requirements functionally so that it can go to the implementation step. However, in the implementation it possible the errors occur so it needs a mentoring process in order to know deeply about its lack.

\section{E. Socialization and Training}

The system that already passed the trial process is readily socialized in the form of training toward the research subject, Renbang LH (the environment of life) and spatial planning for BAPPEDA of Bandung Regency. This system also is socialized to the community who utilize the space in Bandung regency. These socialization and training steps are conducted in the form of a workshop.

\section{CONCLUSION}

The conclusions of this research are as follows:

1) The developed information system in this research can be used for information dissemination of regional spatial planning map (RTRW) in Bandung Regency so it is easily accessed by the community who will utilize the space in Bandung Regency area.

2) The implementation of participatory GIS concept on the geographic information system of regional spatial allows the participation of all communities in making decisions on the use of an area. Therefore, the resulting space placement plan can represent the interests of all community groups and local residents. The participatory GIS approach can be applied to other districts across Indonesia for mapping the community land use practices in Spatial Planning Regulation.

\section{ACKNOWLEDGMENT}

Thank you to UNIKOM, KEMENRISTEKDIKTI, Bandung Regency Government which has supported this research. Members of the Department of Information System are helped for completing research. Especially thanks to Chief Department of Unikom Research Institute, Dr. Ir. Lia Warliana, M.Si. has remembered me about milestone report.

\section{REFERENCES}

[1] Undang-Undang Republik Indonesia Nomor 26 Tahun 2007 Tentang Penataan Ruang.

[2] Peraturan Daerah Kabupaten Bandung Nomor 27 Tahun 2016 Tentang Rencana Tata Ruang Wilayah Kabupaten Bandung Tahun 2016-2036.

[3] Meenar, Mahbubur R. Using participatory and mixed-methods approaches in GIS to develop a Place-Based Food Insecurity and Vulnerability Index. Environment and Planning A: Economy and Space, vol. 49 no. 5, pp. 1181-1205, 2017.

[4] Corbett, J., Cochrane, L. and Gill, M. Powering Up: Revisiting Participatory GIS and Empowerment. The Cartographic Journal, vol. 53 no. 4, pp. 335-340, 2016.

[5] Sulistyawan, B.S., et al. Integrating participatory GIS into spatial planning regulation: The case of Merauke District, Papua, Indonesia. International Journal of the Commons, vol. 12 no. 1, pp. 25-59, 2018.

[6] Fahrul, A. The Study of Integration of "GIS Participatory-Decision Support" in Regional Spatial Management. Jurnal Informatika Mulawarman, vol. 7 no. 1, pp. 1-7, 2012.

[7] Fu, P. and Sun, J. Web GIS: Principles and Applications. United State: Esri Press, 2010.

[8] Boroushaki, S. and Malczewski, J. Participatory GIS: a web-based collaborative and multicriteria decision analysis. Journal of the Urban and Regional Information Systems Association, vol. 22 no. 1, pp. 23-32, 2010.

[9] Zolkafli, A., Brown, G. and Liu, Y. An Evaluation of Participatory GIS (PGIS) for Land Use Planning in Malaysia. The Electronic Journal of Information Systems, vol. 83 no. 1, pp. 1-26, 2017.

[10] Angelina, S. Making Transportation and Land-Use Planning in Indonesia Sustainable (Lesson Learned from Germany). Conference: The 18th FSTPT International Symposium, Indonesia, 2015.

[11] Kendall, Kenneth E., Kendall, Julie E. Systems Analysis and Design, 9th ed. New Jersey: Pearson Prentice Hall, 2013.

[12] Putra, N. Research and Development. Depok: RajaGrafindo Persada, 2011.

[13] Larrea, M. Black-Box Testing Technique for Information Visualization. Sequencing Constraints with Low-Level Interactions. Journal of Computer Science and Technology, vol. 17 no. 1, pp. 37-48, 2017. 